Editorial

\title{
Introduction to Migration and Refugee Flows: New Insights
}

\author{
Inmaculada Martínez-Zarzoso ${ }^{1,2}$ \\ ${ }^{1}$ Department of Economics, University of Göttingen, Germany; E-Mail: imartin@gwdg.de \\ 2 Department of Economics, Jaume I University, Spain; E-Mail: martinei@uji.es
}

Submitted: 30 September 2021 | Published: 28 October 2021

\begin{abstract}
Population movements between countries and continents are not recent phenomena. What is new today is that migration flows are increasingly linked to the globalization process and to environmental degradation. Most of the migrants leave their homes for economic reasons, but also due to the higher frequency of natural disasters. Of the total migrant population, those who escape from conflicts or persecution still represent a smaller fraction and are entitled to obtain refugee status. This thematic issue includes eight articles that analyse migration flows and migration governance from different analytical perspectives. Five of the eight contributions examine the role that several factors play in explaining international migration flows and its effects, namely cultural diversity, information technology tools, governance, terrorism, and attitudes towards immigration. The remaining three articles are country studies that analyse the socioeconomic causes/effects of migration flows to Portugal, Spain, and Germany, devoting special attention to forced migration and refugees.
\end{abstract}

\section{Keywords}

asylum; cultural diversity; Germany; governance; information technology; migration; Portugal; refugees; Spain; terrorism

\section{Issue}

This editorial is part of the issue "Migration and Refugee Flows: New Insights" edited by Inmaculada Martínez-Zarzoso (University of Göttingen, Germany / Jaume I University, Spain).

(C) 2021 by the author; licensee Cogitatio (Lisbon, Portugal). This editorial is licensed under a Creative Commons Attribution 4.0 International License (CC BY).

\section{Introduction}

In the late 2000s Europe faced growing migration flows from the African continent following the Arab Spring and the growing instability in North Africa and the Middle East. This process exacerbated in 2015 when Germany announced a welcoming policy, which led to a massive arrival of immigrants and to the consequent opposition from a number of other European countries, such as Hungary, which did perceive this policy as a negative example. Other regions in the world were also affected by similar problems, such as those caused by the Venezuelan crisis or ethnic persecution in Asia. These migration crises, emerging in different parts of the world, highlight the inadequacy of the existing governance structures of the national and supra-national institutions. In practice, the solution proved difficult, and the question of how to deal with migrants remains unsolved.

The aim of this thematic issue is to analyse migration flows and migration governance from different ana- lytical perspectives. The contributions include the analysis of the socio-economic determinants of international migration flows not only at a global level, but also in a number of host countries, namely Germany, Portugal, and Spain. This thematic issue covers aspects related to the following: migration governance in developing and developed countries and its implications; the changing dynamics in international migrations and the examination of information technology tools to predict the flows; the economic effects of the migrants' cultural diversity, as well as the effects of terrorism and other political factors on emigration; the interlink between migration and governance of the receiving countries in rural areas; and the different determinants of refugee flows and international migration.

\section{Factors Explaining International Migration Flows}

The first contribution by Maite Alguacil and Luisa Alamá-Sabater entitled "Migration in Spain: The Role of 
Cultural Diversity Revisited" examines the link between immigrant cultural diversity and economic performance at the provincial level. The authors use data for immigrants arriving to Spanish provinces over a period of 14 years and use econometric techniques to disentangle the differences between working and retired migrants. The main results of the analysis indicate that, in the case of labour-active immigrants, greater cultural diversity stimulates economic activity and these gains are reinforced when migrants come from developing countries. The main implication of this research is that the misperception that citizens have, concerning the potential negative effects from immigrants in the labour market, should be counteracted by providing information to the general public about the positive economic effects coming from cultural diversification, such as the ones found in this article (Alguacil \& Alamá-Sabater, 2021).

Another important aspect of international migration is that host countries are not always able to predict future international migration trends accurately; this is the topic covered in "The Role of Emerging Predictive IT Tools in Effective Migration Governance" by Cristina Blasi Casagran, Colleen Boland, Elena Sánchez-Montijano, and Eva Vilà Sanchez. Their study examines three predictive tools using a comparative qualitative approach, considering their scope and the links to the corresponding migration theories, research questions, and objectives. The tools examined are: the JETSON tool, operated by UNHCR; the Early Warning and Preparedness System used by the European Asylum Support Office; and FORESIGHT, operated by the Danish Refugee Council. The question posed by the authors does not seem to have an easy answer. Despite the importance of the tools examined, the authors find that many difficulties are faced by those managing the predictive tools and provide several factors that should be taken into consideration to improve the tools. These include the following: more guidance on how to select variables to be incorporated into the models; searching ways to involve end-users in the process; improving the accuracy of the tools; and, finally, tailoring the modelling of the prediction to specific governance objectives (Blasi Casagran et al., 2021).

The economic literature that examines the "push factors" explaining forced migration has rarely considered that most people forced to flee, move within their own country. The main novelty of the next contribution "Asylum Migration, Borders, and Terrorism in a Structural Gravity Model," by Federico Carril-Caccia, Jordi Paniagua, and Francisco Requena, is an analysis of the impact of terrorist attacks on asylum migration using a gravity equation that includes both international migration and internally displaced people. This framework is suitable to identify the effect of country-specific factors, such as terrorist attacks. Using information on asylum applications, internally displaced persons, and terrorist attacks for a global sample of countries in the last decade, the empirical results indicate that despite the fact that asylum migration is still low compared to internal migra- tion, globalization forces are pushing up the former. The authors also find that terrorist attacks have a positive and significant effect on forced migration. Moreover, some regional heterogeneity in the effect of terrorism on asylum is found, showing that terrorist attacks have a much larger impact on asylum applications in Latin America than in Asia or Africa (Carril-Caccia et al., 2021).

In relation to the controversial issue around the public opinion about international migration, Teresa María García-Muñoz and Juliette Milgram-Baleix in their article "Explaining Attitudes Towards Immigration: The Role of Economic Factors" analyse the determinants of the individuals' opinions with respect to the economic impact of immigrants in the host country. The main novelty of their analysis is the use of a global sample. The methodology used is a multilevel model, which is employed to investigate the effect of the individuals' characteristics and macroeconomic variables on the assessment of immigrants' impact on development. The main results indicate that migrants are perceived as potential substitutes of low- and middle-skilled workers in capitalabundant countries and that closer contact with immigrants seems to reduce anti-immigrant opinions. This is the case for skilled workers and, hence, education is one of the best tools to change inaccurate perceptions when assessing the role played by immigrants in the host country (García-Muñoz \& Milgram-Baleix, 2021). Also dealing with attitudes towards migrants and refugees, but in this case for a specific world region-the "Visegrad Four" the article by Artur Gruszczak “'Refugees' as a Misnomer: The Parochial Politics and Official Discourse of the Visegrad Four" explores the official policy responses to the refugee crisis in the four Central European countries: Poland, Hungary, Slovakia, and the Czech Republic. The main methodology framework consists of a qualitative content analysis supplemented by the findings of public opinion polls. The author concludes that the migration crisis alarmed the traditional cleavages at the supra-local level, reinforcing simultaneously the sense of parochial altruism and hostility towards migrants (Gruszczak, 2021).

\section{Country Case Studies}

Although many immigrants tend to choose big cities as destinations, it is also crucial to examine the challenges faced by rural communities to govern international migration. In their contribution, Inês Cabral and Thomas Swerts deal with the issue of "Governing Precarious Immigrant Workers in Rural Localities: Emerging Local Migration Regimes in Portugal" and focus on a case study in the locality Odemira, where the presence of precarious immigrant workers is perceived as a policy problem by the local government and the civil society. The authors examine the consequences of the increasing migration to rural areas in Southern Europe, which is partly generated by the globalization of the agricultural sector combined with the declining and ageing 
workforce in the countryside that creates a demand for immigration labour. The article examines the emerging local migration regimes in Odemira and concludes that balancing power relations between actors could help to improve the living and working conditions of precarious immigrant workers by improving arrival infrastructures, stimulating integration, mediating the sociocultural impact, and accommodating business interest (Cabral \& Swerts, 2021).

Motivated by the increasing number of far-right political parties that oppose migration in Europe, the article "Undocumented Migration and Electoral Support: Evidence From Spain," by Ismael Gálvez-Iniesta and José L. Groizard, focuses on the Spanish case that was described as peculiar in Mendez and Cutillas (2014), indicating that immigration led to more support for the left than for the right parties in presidential elections in Spain. Using recent data, this article finds that an increase in the share of irregular migrants increases the share of votes to the conservative party but has no impact on the vote share of the socialist party. Contrarily, voters respond to rising regular migration by favouring the socialist party and no effect is found on the vote share of the right. The inclusion of new political forces, such as VOX, to test the role played by immigration and national-identity discourse in the general elections that took place after the refugee crisis, could explain this result. While increasing shares of irregular immigrants change the distribution of the share of votes from the left to the right, greater proportions of regular immigrants reduce support for the right and the far-right. Summarizing, the results show that the right has capitalized on the narrative of restricting irregular migration and Spaniards' voting behaviour does not differ from this in neighbouring European countries (Gálvez-Iniesta \& Groizard, 2021).

Finally, the study by Felicitas Nowak-Lehmann, Adriana Cardozo, and Inmaculada Martínez-Zarzoso, entitled "Migration and Asylum Flows to Germany: New Insights Into the Motives," examines the determinants of both international migration and asylum migration from developing countries to Germany. A gravity model is estimated that includes climate change, economic opportunities, links to Germany, the political and institutional situation in the sending countries, and a control for migration opportunities to alternative destinations. The most interesting findings are revealed when considering country-groupings heterogeneity. For total migration levels, moderate migration-decreasing effects are found for weaker migrant networks in Germany, smaller population growth differences between the countries of origin and Germany, relative economic progress in the countries of origin, and improvement of socioeconomic factors, such as poverty, unemployment, and consumer confidence. Consistent migration-decreasing effects are also linked to improvements of political factors in the sending countries. Concerning asylum migration, improvements in ethnic tensions or internal conflict are associated with a lower number of asylum applications. These reductions are very pronounced for countries with a low asylum recognition rate. Better economic and socioeconomic conditions in origin countries, such as relative improvements in per capita income, consumer confidence, and employment are associated with a reduction in asylum requests. However, alleviation of poverty seems to propel asylum migration suggesting that improved economic conditions, together with the help of families and facilitators, can make emigration feasible and affordable. Finally, increasing average temperatures is found to trigger emigration among asylum seekers. Interestingly, the majority of asylum seekers comes predominantly from countries located in arid and semi-arid regions, where increasing average temperatures lead to drought with concomitant high losses in agriculture (Nowak-Lehmann et al., 2021).

\section{Conclusions}

The eight articles presented in this thematic issue deal with current issues at the global, country, and municipality level, opening a black box of potential explanations concerning the factors that explain migration, as well as the socio-economic and political consequences of migration for the host countries. Further research should extend the work offered by these contributions to other regions of the world, as well as provide additional case studies to enrich the new insights around the research area of migration and refugee flows.

\section{Acknowledgments}

I would like to thank the anonymous referees and the editors for their helpful comments and suggestions. I am also grateful to the financial support received from Project PID2020-114646RB-C42 (Ministerio de Economía y Competitividad) and from projects UJIB2020-57 (Universitat Jaume I) and PROMETEO2018/ 108 (Generalitat Valenciana).

\section{Conflict of Interests}

The author declares no conflict of interests.

\section{References}

Alguacil, M., \& Alamá-Sabater, L. (2021). Migration in Spain: The role of cultural diversity revisited. Politics and Governance, 9(4), 118-132.

Blasi Casagran, C., Boland, C., Sánchez Montijano, E., \& Vilà Sanchez, E. (2021). The role of emerging predictive IT tools in effective migration governance. Politics and Governance, 9(4), 133-145.

Cabral, I., \& Swerts, T. (2021). Governing precarious immigrant workers in rural localities: Emerging local migration regimes in Portugal. Politics and Governance, 9(4), 185-195. 
Carril-Caccia, F., Paniagua, J., \& Requena, F. (2021). Asylum migration, borders, and terrorism in a structural gravity model. Politics and Governance, 9(4), 146-158.

Gálvez-Iniesta, I., \& Groizard, J. L. (2021). Undocumented migration and electoral support: Evidence from Spain. Politics and Governance, 9(4), 196-209.

García-Muñoz, T. M., \& Milgram-Baleix, J. (2021). Explaining attitudes towards immigration: The role of economic factors. Politics and Governance, 9(4), 159-173.
Gruszczak, A. (2021). "Refugees" as a misnomer: The parochial politics and official discourse of the Visegrad Four. Politics and Governance, 9(4), 174-184.

Mendez, I., \& Cutillas, I. M. (2014). Has immigration affected Spanish presidential elections results? Journal of Population Economics, 27(1), 135-171.

Nowak-Lehmann, F., Cardozo, A., \& Martínez-Zarzoso, I. (2021). Migration and asylum flows to Germany: New insights into the motives. Politics and Governance, 9(4), 210-223.

\section{About the Author}

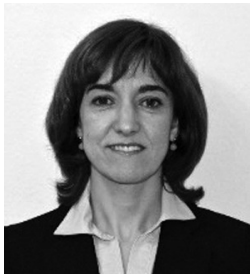

Inmaculada Martínez-Zarzoso is professor at the Universities of Göttingen (Germany) and Jaume I (Spain). She is also vice-chair of the International Network for Economic Research (INFER) and board member of the Centre for Global Migration Studies (CEMIG). She is the author of two books and of more than 100 articles in academic journals, including the Journal of International Economics and the Journal of Development Economics, in the fields of international and development economics. https://orcid.org/0000-0002-3247-8557 